\title{
Tree species identity mediates mechanisms of top soil carbon sequestration in a Norway spruce and European beech mixed forest
}

\author{
Enrique Andivia $^{1,2}$ (I) - Victor Rolo ${ }^{1,3} \cdot$ Mathieu Jonard $^{2}$. \\ Pavel Formánek $^{4} \cdot$ Quentin Ponette ${ }^{2}$
}

Received: 25 August 2015 / Accepted: 28 December 2015 / Published online: 14 January 2016

(C) INRA and Springer-Verlag France 2016

\begin{abstract}
- Key message Combined effects of litterfall and root turnover significantly increase topsoil carbon stocks in Norway spruce and European beech mixed forests, indicating local complementarity effects mediated by tree species mixtures.

- Context The establishment of mixed stands by intermingling individuals of European beech and Norway spruce is an ongoing trend in adaptive forest management strategies. However, our understanding of the potential of these strategies to promote $\mathrm{C}$ sequestration remains limited.

- Aims This study aims to assess the effect of species composition on SOC stock in a mixed forest of Norway spruce and European beech.

- Methods We studied C stocks in the uppermost soil layers in two stands dominated either by Norway spruce or European

Handling Editor: Shuqing Zhao

Contribution of the co-authors EA and VR conceived the idea, designed and conducted the field sampling, performed the data analysis, and wrote the manuscript. MJ, PF, and QP revised the manuscript and participated in the discussion of the results.
\end{abstract}

Enrique Andivia

e.andivia@gmail.com

1 Department of Silviculture, Faculty of Forestry and Wood Technology, Mendel University, Brno, Czech Republic

2 Earth and Life Institute, Université catholique de Louvain, Croix du sud 2, L7.05.09, 1348 Louvain-la-Neuve, Belgium

3 Present address: Conservation Ecology Research Unit, Faculty of Natural and Agricultural Sciences, University of Pretoria, Pretoria, South Africa

4 Department of Geology and Pedology, Faculty of Forestry and Wood Technology, Mendel University, Brno, Czech Republic beech and in a mixture of both species. We evaluated the effect of litterfall and root turnover on soil organic carbon (SOC) stocks and its spatial distribution by combining structural equation models and geostatistical techniques.

- Results C stocks in the forest floor were highest in Norway spruce, whereas in the mineral soil, the highest values were in the mixed stand. The proportion of Norway spruce litterfall was positively related to $\mathrm{C}$ stock in the forest floor across stands. Root turnover was positively related to $\mathrm{C}$ stock in the mineral soil of the mixed stand.

- Conclusion Our results confirm a contrasting role of root turnover and litterfall between soil layers in the studied stands, suggesting that tree species composition can mediate the spatial distribution of SOC stocks in mixed forests.

Keywords Soil organic carbon $\cdot$ Forest floor $\cdot$ Litterfall $\cdot$ Root turnover · Tree species admixture · Forest management .

Spatial variability

\section{Introduction}

Forests play an important role in the global carbon (C) cycle and in the Earth's terrestrial $\mathrm{C}$ sink. Forest ecosystems contain approximately $1725 \mathrm{Pg}$ of $\mathrm{C}$ and about two thirds are contained in the forest soil (Pan et al. 2011). However, there is still large uncertainty concerning the drivers and the feasibility of management strategies aimed at promoting soil organic carbon (SOC) sequestration (Jandl et al. 2014; Stockmann et al. 2013). Jandl et al. (2007) reviewed forest management practices affecting $\mathrm{C}$ stocks, providing management strategies that are directly related to $\mathrm{C}$ sequestration. Among them, those practices oriented toward increased ecosystem resilience, such as mixing of different tree species, have been identified as suitable actions. The introduction of 
native species (e.g., European beech) into monospecific plantations (e.g., Norway spruce) is an ongoing trend in silviculture that aims toward more "natural" forestry. This close-tonature forestry implies an increasing focus on adaptation to climate change and ecosystem services (O'Hara 2014). None theless, our understanding of the potential of these strategies to promote $\mathrm{C}$ sequestration still remains limited, and there is a lack of scientific consensus regarding the effect of the mixture of tree species on SOC stock (Vesterdal et al. 2013). More over, studies about species composition effect on SOC stock are often conducted at landscape or stand scale and, to the best of our knowledge, there are no examples at a finer scale in mixed forests. Assessing the spatial variability of SOC stocks combined with information on spatial distribution of tree spe cies and $\mathrm{C}$ inputs may potentially be used to get insights into the underlying mechanisms governing $\mathrm{C}$ accumulation in mixed forests.

Different tree species can have differential effect on the mechanisms that mediate the $\mathrm{C}$ cycle (Augusto et al. 2015). Thus, their intermingling can have a profound effect on $\mathrm{C}$ accumulation rates and SOC distribution within the soil profile (Chapin 2003). These evidences are the basis for the establishment of mixed forest to promote soil $\mathrm{C}$ sequestration as compared to monospecific stands. For instance, conifers species generally accumulate greater SOC stock in the forest floor layers than do deciduous species (Augusto et al. 2015). On the other hand, the greater root biomass found in deciduous forests (Finér et al. 2007) together with the importance of root litter as $\mathrm{C}$ input to the mineral soil might induce a greater $\mathrm{C}$ accumulation in the mineral soil under broadleaf species. Thus, different mechanisms underpin $\mathrm{C}$ accumulation in forest soils under different tree species. Indeed, $\mathrm{C}$ inputs to forest soil are determined to a great extent by the type of vegetation, directly by above and belowground litter inputs, which in turn, depending on the amount and characteristics, will determine the rate of soil organic matter formation (Berg 2000; Hansson et al. 2013). However, studies assessing the contribution of the aboveground compartment, as compared to the belowground, are overrepresented despite that differences in belowground functioning may play a key role (Wardle et al. 2004). Causal influences among these variables can be partitioned using structural equation models (SEM; Grace 2006). SEM has been shown to be a powerful tool to study multiple processes operating in complex system and may allow us to interpret tree species effects on SOC stock and distribution (Augusto et al. 2015; Vesterdal et al. 2013) and, thus, to better understand the consequences of human interventions that aim at enhancing $\mathrm{C}$ sequestration.

We aimed at disentangling the effect of local species composition on SOC stock in mixed forests of Norway spruce and European beech. Specifically, we measured two important processes of the $\mathrm{C}$ cycle: litterfall and root turnover. Based on known differences in litterfall chemical composition and microenvironment between conifer and broadleaved stands (Berg 2000; Prescott et al. 2000), we hypothesized (i) a higher accumulation of $\mathrm{C}$ in the forest floor under Norway spruce and in the topsoil under European beech; (ii) that SOC accumulation in the forest floor is mainly driven by the proportion of litter of both species (litter quality); whereas (iii) both, litter quality and root turnover, control SOC stocks in the top mineral soil; and (iv) that spatial variability in SOC stocks is related to the spatial distribution of tree species in the mixed stand.

\section{Material and methods}

\subsection{Study area}

The study area was located in the Masaryk forest, a forest managed by the Training Forest Enterprise of the Mendel University in Brno (Czech Republic). The forest is approximately 10,500 ha and about a third of the total surface is within the protected landscape of the Moravian Karst. The forest area ranges in altitude from 210 to $575 \mathrm{~m}$ a.s.l., in mean annual temperature from 6.5 to $8.4{ }^{\circ} \mathrm{C}$ and in annual precipitation from 550 to $700 \mathrm{~mm}$. Geological parent material in the area was formed by acidic granodiorite. The Masaryk forest mainly consists of mixed stands of conifers and deciduous tree species.

We selected three adjacent areas (1 ha each, hereafter plots) within the Masaryk forest enterprise near Rudice (Czech Republic, $49^{\circ} 19^{\prime} \mathrm{N} 16^{\circ} 43^{\prime} \mathrm{E}$ ), two plots in zones dominated either by Norway spruce or by European beech (namely $S$ and $B$, respectively) and one with a mixture of both species $(M)$. The age class of the selected plots was between 81 and 100 years old. Stand density and basal area (Table 1) were typical of monodominant and mixed stands of these two species in the area, according to major forest management types of the Forest Inventory Database of the Czech Republic (UHUL 2007). Plots were selected in such a way that species composition was the main varying factor (Table 1); they were all situated at the same elevation (502$530 \mathrm{~m}$ ), slope position, and parent material. The mean distance between plots was $350 \mathrm{~m}$. The texture of soils was silty-loam, and they were classified as Leptic Cambisols (IUSS 2006). Historically, the area has been occupied by forests and it has been traditionally managed for decades through selective thinning. There were no signs of recent tillage or site preparation at the selected stands as the mineral topsoil remained undisturbed at the time of sampling.

\subsection{Forest soil sampling and analysis}

At each plot, a rectangle of $50 \times 30 \mathrm{~m}$ was installed in a flat area and the positions of all trees were recorded in a local 
Table 1 Dendrometric and soil characteristics of the experimental plots

\begin{tabular}{llll}
\hline & European beech & Norway spruce & Mixture \\
\hline $\begin{array}{l}\text { Dendrometric characterization } \\
\text { Stand density }\left(\text { tree ha }^{-1}\right)\end{array}$ & 460 & & \\
Basal area $\left(\mathrm{m}^{2} \mathrm{ha}^{-1}\right)$ & 21.8 & 1260 & $812(326 \mathrm{~B}, 486 \mathrm{~S})$ \\
DBH (cm) & $22.2 \pm 1.3$ & 49.5 & $45.2(17.7 \mathrm{~B}, 27.5 \mathrm{~S})$ \\
Height (m) & $25.7 \pm 0.9$ & $21.1 \pm 0.5$ & $24.7 \pm 0.9$ \\
Soil conditions (uppermost $10 \mathrm{~cm})$ & & $20.0 \pm 0.7$ & $18.3 \pm 0.7$ \\
Clay (\%) & 13.6 & & \\
Silt (\%) & 65.6 & 15.5 & 16.5 \\
Sand (\%) & 20.8 & 72.1 & 55.4 \\
$\mathrm{pH}(\mathrm{H}-\mathrm{O})$ & 4.0 & 12.3 & 28.1 \\
$\mathrm{pH}(\mathrm{KCl})$ & 2.9 & 3.8 & 3.7 \\
\hline
\end{tabular}

European beech $(B)$ and Norway spruce $(S)$ densities and basal area in the mixed plot are showed within parentheses. Standard error of the mean is given for DBH and height coordinate system using the Field-Map technology setup (IFER-MMS, Czech Republic). For each tree, tree species identity (European beech or Norway spruce), height, diameter at breast height $(\mathrm{DBH})$, and eight crown radii were measured (Table 1). Forest floor and mineral soil samples were collected at each plot in the interception points of an approximate $5 \times 5-\mathrm{m}$ grid established within the $1500 \mathrm{~m}^{2}$ selected area. The sampling protocol resulted in 77 points per plot that were sampled in mid-September 2013. Each sampling point was georeferenced within the local coordinate system with FieldMap, and ancillary data such as elevation was recorded. Undisturbed soil samples were collected with a $750-\mathrm{cm}^{3}$ soil sampler (8-cm diameter, Model M1-0502, Eijkelkamp, Netherlands). For each sample, the litter component $(O l)$, the decomposed organic matter $(O f+O h)$, and the top $10 \mathrm{~cm}$ of mineral soil $(M S)$ were separated. Coarse woody material, such as large branches, were carefully removed from the forest floor before sampling. $\mathrm{Ol}$ was described as non-decomposed fallen plant material and $O f+O h$ consisted of partly or strongly decomposed organic material (see van Delft et al. 2006). The thickness of the $O l$ and $O f+O h$ layers was measured in the field $( \pm 0.1 \mathrm{~cm})$. We sampled the top $10 \mathrm{~cm}$ of mineral soil because tree species have the greatest impact on the uppermost layers of the mineral soil (Augusto et al. 2002; Hagen-Thorn et al. 2004), and the top $10 \mathrm{~cm}$ of mineral soil roughly represents the $35-40 \%$ of the total SOC stock down to $100 \mathrm{~cm}$ soil depth in Norway spruce and European beech forests (Galka et al. 2014). Moreover, recent studies show that signif icant differences in $\mathrm{C}$ sequestration between conifers and de ciduous species over the last decades in French forests have only occurred at the uppermost $20 \mathrm{~cm}$ (Jonard et al. 2013).

All samples $(O l, O f+O h$, and $M S)$ were oven-dried at $105^{\circ} \mathrm{C}$ for $24-48 \mathrm{~h}$ and weighed $( \pm 0.01 \mathrm{~g})$ for calculation of bulk densities. Roots were manually separated from the $O f+$ $O h$ and the $M S$ samples and weighed $( \pm 0.001 \mathrm{~g}) . O l$ and $O f+$ Oh samples were ground with a micro mill to pass a $250-\mu \mathrm{m}$ mesh. $M S$ samples were first passed through a 2-mm sieve, and stones and root were separated. $M S$ density was corrected by subtracting the mass and the volume of stones and roots. The volume of the removed material (i.e., stones and roots) was calculated by water displacement. Sieved soil was ground on a mortar until soil sample passed through a $250-\mu \mathrm{m}$ mesh. Carbon and nitrogen contents were then determined in all samples and layers by high-temperature $\left(1000^{\circ} \mathrm{C}\right)$ dry combustion method with an automatic analyzer LECO CNS 2000.

\subsection{Litterfall and root turnover}

We used a leaf fall dispersal model to estimate the amount of European beech and Norway spruce leaf fall at each sampling point in the plots. The model was fitted by collecting litterfall in 18 randomly selected points at each plot by using circular plastic baskets $\left(28 \mathrm{~cm} \varnothing, 0.06 \mathrm{~m}^{2}\right)$. Litterfall traps were established at the middle of September 2012, and litterfall was collected during 1 year at a 3-month interval. Litterfall samples were immediately oven-dried at $70{ }^{\circ} \mathrm{C}$ during $48 \mathrm{~h}$, separated into European beech and Norway spruce foliar and non-foliar litterfall and weighed $( \pm 0.01 \mathrm{~g})$. Litterfall production $\left(\mathrm{g} \mathrm{m}^{-2}\right)$ was calculated by dividing the total litterfall dry weight (foliar and non-foliar) by the trap surface. Briefly, leaf fall production and dispersal models consider that the annual amount of leaf fall at a location $i\left(q_{i}\right)$ is the sum of the contributions of neighboring trees. The contribution of a tree $j$ to the location $i$ is estimated by multiplying the leaf fall production of tree $j$, estimated based on allometric equations function of stem circumference $(\mathrm{CBH})$, by the probability density that leaves from that tree fell at location $i$ (see Jonard et al. 2006 for a complete description of the theoretical framework of leaf dispersal modeling). Leaf fall production and dispersal models mainly differ in the modeling of the probability density of leaf shedding with distance. In our study, we used the model developed by Ferrari and Sugita (1996) that considers an 
exponential decline of the dispersal function with distance from the source tree $\left(d_{j i}\right)$. Thus, the final model is

$q_{i}=\sum_{j} a \times\left(C B H_{j}\right)^{\beta} \times \frac{1}{N_{0}} \times \exp \left(-\gamma \times d_{j i}\right)$

where $N_{0}$ is a normalization constant obtained by integrating over distance $(0-60 \mathrm{~m})$ the dispersal function multiplied by $2 \pi d_{j i} . \alpha, \beta$, and $\gamma$ are model parameters that have to be estimated for each species. Model parameters were estimated by the maximum likelihood ratio following the procedure described in Jonard et al. (2006). The performance of the model was validated on the basis of correlations between the measured and predicted litterfall amounts. Norway spruce litter proportion was then calculated as the percentage of needle fall at one point related to the total amount of leaves and needle fall at that point.

The ingrowth core method was used to estimate root production in the upper $10 \mathrm{~cm}$ of the soil profile $(M S)$ in the three plots during one growing season (March 2013-September 2013). Ingrowth cores were made with fiberglass bags (10 cm long, $8 \mathrm{~cm}$ in diameter, $2 \mathrm{~mm}$ mesh), filled with root-free soil from the study site, sieved at $4 \mathrm{~mm}$. Eighteen ingrowth cores were placed at each plot at the beginning of the growing season and carefully pressed with a metal bar to ensure a similar bulk density to that of the field site. After the growing period, bags were extracted with the surrounding soil to avoid roots from being pulled out of the mesh bag during retrieval. Roots were sorted by hand, washed, oven-dried at $70{ }^{\circ} \mathrm{C}$ during $48 \mathrm{~h}$ and weighed $( \pm 0.001 \mathrm{~g})$. Root turnover was calculated at each soil sampling point as the average value of root production per plot divided by the root biomass collected at each soil sampling point (Gill and Jackson 2000).

\subsection{Data analysis}

C stock of the $O l$ and $O f+O h$ layers was calculated by multiplying carbon concentration by the layer dry mass and dividing by the sampled surface. $\mathrm{C}$ stock in the forest floor layer $(F F)$ was then calculated as the sum of $\mathrm{C}$ stocks of $\mathrm{Ol}$ and $O f+O h$ layers. C stock of the mineral soil was calculated as

$M S C$ stock $=C_{i} \cdot B D_{i} \cdot T_{i}$

where $C_{i}$ is the carbon concentration, $B D_{i}$ is the measured bulk density, and $T_{i}$ is the thickness of the soil sample $(10 \mathrm{~cm})$. Plot comparison was based on dry mass $\left(\mathrm{g} \mathrm{m}^{-2}\right)$, thickness $(\mathrm{cm}), \mathrm{C}$ and $\mathrm{N}$ concentration (\%), $\mathrm{C} / \mathrm{N}$ ratio, bulk density $\left(\mathrm{g} \mathrm{cm}^{-3}\right)$, root density $\left(\mathrm{g} \mathrm{cm}^{-3}\right)$, and $\mathrm{C}$ stock of each layer $(F F$ and $M S$ ) and of their sum (SOC stock). We also analyzed the differences between plots in litterfall and root turnover. Significant differences between plots were assessed by $t$ test at $p<0.05$. All variables were log-transformed to achieve residual homoscedasticity, with the exception of $\mathrm{C}$ and $\mathrm{N}$ concentrations that were transformed using the arcsine square root transformation. All statistical analyses were performed in $\mathrm{R}$ version 3.0.2. The package stats was used to perform $t$ tests.

We used SEM to study the effects of litterfall, root turnover, and a series of environmental factors (microelevation and canopy openness) on $\mathrm{C}$ stocks of each soil layer. Micro-elevation was calculated as the difference between the altitude of each sampling point, measuring by Field-Map and the mean altitude of the area. Canopy openness was calculated as the proportion of gaps in the canopy within an area of $5 \mathrm{~m}$ (distance between adjacent sampling points) around each sampling point. Micro-elevation and canopy openness were used as proxies of environmental factors that have been identified as relevant factors influencing $\mathrm{C}$ stocks (Wälder et al. 2008). We used SEM in an exploratory mode to obtain hypothesized causal models that were both consistent with our data and which made biological sense (Fig. 1). First, we used SEM to assess the effects of the mentioned covariates on $\mathrm{C}$ stocks by considering all the data, then we analyzed if the effect of covariates was consistent when data was analyzed per species composition (i.e., stand). We used a stepwise procedure to identify the most parsimonious model, beginning with all plausible paths between factors, based on the Akaike information criterion (AIC). Chi-square tests were used to assess model fit. SEM analyses were conducted in $\mathrm{R}$ using the lavaan package (Rosseel 2012).

C stock of $F F$ and $M S$ layers was modeled, for each plot, using geostatistical techniques. An empirical semivariogram was calculated and set to a spherical type function, and then range, partial sill $(C)$, and nugget $(C o)$ were estimated. The spatial dependence of each variable was assessed by calculating the portion of the total variance $(\mathrm{C}+\mathrm{Co})$ explained by the spatial autocorrelation (i.e., $\mathrm{C} / \mathrm{C}+\mathrm{Co}$ ). In the mixed plot, $\mathrm{C}$ stocks were interpolated to the whole plot by using ordinary and universal kriging and following the procedure in Rossiter (2007). Universal kriging can take into account known auxiliary variables at each sampled and unsampled points to model the response variable. Those significant factors resulting from SEM analyses were used as co-variables in the universal kriging of both forest soil layers in order to evaluate if they significantly improved the modeling of the SOC stock spatial variability. All predictions were isotropic and predominant directions were not observed. The accuracy of the kriging predictions was evaluated by cross-validation at the 77 soil sampled points. The diagnostic was based on the parameters: mean error $(M E)$, root mean square error (RMSE), and mean squared deviation ratio $(M S D R)$ of the residuals to the prediction error. Geostatistical analyses were performed using the $\mathrm{R}$ package gstat and following the recommendations of Hengl (2007) and Rossiter (2007). 
Fig. 1 Generic design of the structural equation models showing all possible causal paths between manifest variables (boxes) and $\mathrm{C}$ stock in forest soil layers (grey ellipses). Manifest variables are considered as proxies of the species identity and microenvironmental effects on $\mathrm{C}$ accumulation in forest soil layers. Single-headed arrows denote a direct influence in the model in the direction of causality; doubleheaded arrows represent interactions

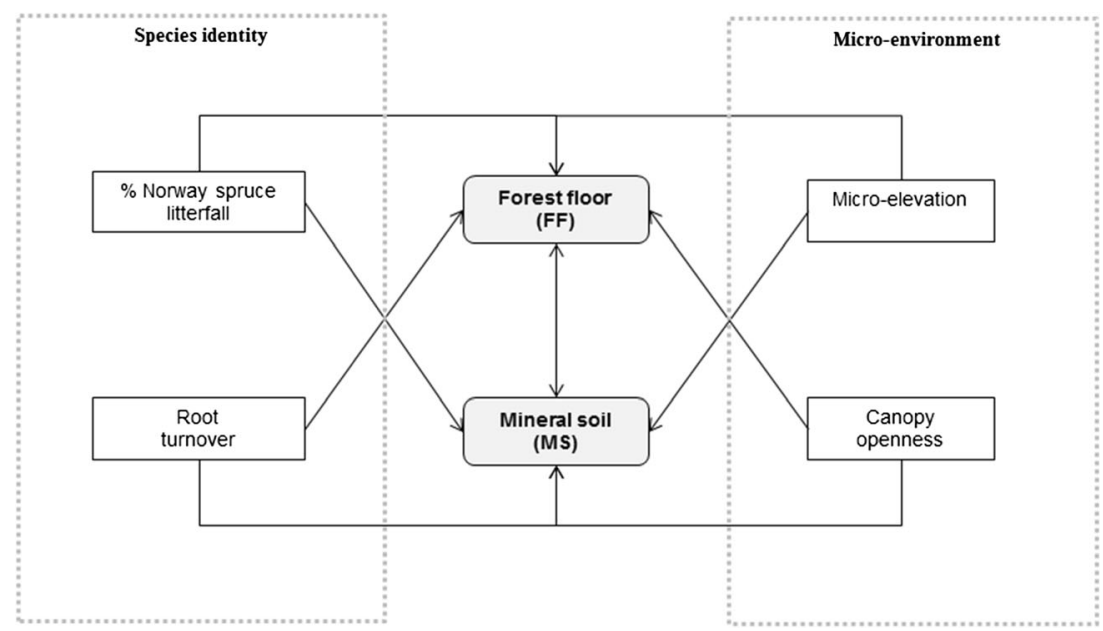

\section{Results}

\subsection{Species composition effect on forest soil characteristics and SOC stocks}

SOC stock $(F F+\mathrm{MS})$ was significantly greater in the Norway spruce $\left(75.76 \pm 1.35 \mathrm{Mg} \mathrm{C} \mathrm{ha}^{-1}\right)$ and mixed plots (74.92 $\left.\pm 2.05 \mathrm{Mg} \mathrm{C} \mathrm{ha}^{-1}\right)$ than under European beech $(53.97$ $\left.\pm 0.96 \mathrm{Mg} \mathrm{C} \mathrm{ha}^{-1}\right)$. Nonetheless, the magnitude of the effect of species composition on SOC stock was dependent on the analyzed soil layer. The thickest forest floor was found under Norway spruce (Table 2) leading to a significant greater accumulation of organic matter and $\mathrm{C}$ stock in the forest floor under this species $\left(33.83 \pm 0.90 \mathrm{Mg} \mathrm{C} \mathrm{ha}^{-1}\right)$, especially in the $O f+O h$ layer (Table 2). The lowest organic matter accumulation and $\mathrm{C}$ stock in the $F F$ layer was found under European beech $\left(12.24 \pm 0.46 \mathrm{MgC} \mathrm{ha}^{-1}\right)$, while the $\mathrm{C}$ stock under the mixture of both species was between both values $(25.55$ $\left.\pm 1.10 \mathrm{Mg} \mathrm{C} \mathrm{ha}{ }^{-1}\right)$. Root density in the forest floor paralleled these results (Table 2). On the other hand, the greatest $\mathrm{C}$ stock in the top $(10 \mathrm{~cm})$ mineral soil was found in the mixed plot (49.37 $\pm 1.48 \mathrm{Mg} \mathrm{C} \mathrm{ha}^{-1}$, Table 2) as compared to both monodominant stands that showed similar values (41.93 $\pm 0.98 \mathrm{Mg} \mathrm{Cha}^{-1}$ in $S$ and $41.73 \pm 0.81 \mathrm{MgC} \mathrm{ha}^{-1}$ in $B$ ). This greater accumulation of $\mathrm{C}$ in the mixed stand was related to the greater $\mathrm{C}$ concentration and the lower bulk density of the top mineral soil. Contrary to $\mathrm{C}$ stock, the root density in the $M S$ layer was significantly greater under Norway spruce and European beech than in the mixture (Table 2).

\subsection{Litterfall and root turnover}

We found no significant differences in litterfall between plots. Litterfall was $4.10 \pm 0.28 \mathrm{Mg} \mathrm{ha}^{-1}$ in the European beech plot, $4.02 \pm 0.21 \mathrm{Mg} \mathrm{ha}^{-1}$ in the Norway spruce plot, and 4.45 $\pm 0.16 \mathrm{Mg} \mathrm{ha}^{-1}$ in the mixture. The predicted and observed values for litterfall amounts were strongly correlated for Norway spruce and European beech $\left(R^{2}=0.83\right.$ and $R^{2}=0.76$, respectively) with similar observed and estimated mean values and proportion for each species at each plot. Root turnover was significantly greater $(p<0.05)$ in the mixed and the European beech plot $\left(1.00 \pm 0.23\right.$ year $^{-1}$ in $M$ and 0.97 \pm 0.15 year $^{-1}$ in $B$, respectively) than in the Norway spruce plot $\left(0.64 \pm 0.10\right.$ year $\left.^{-1}\right)$.

\subsection{Factors affecting SOC stock}

SEMs showed that the proportion of Norway spruce in litterfall and the root turnover were the main factors affecting $\mathrm{C}$ stocks when data from the three plots were analyzed together (Fig. 2). C stock in the $F F$ directly increased (standardized path coefficient $(\mathrm{SD})=0.84$, Fig. 2) as the proportion of Norway spruce increased in the litterfall. Microelevation and the amount of canopy openness were also related to $\mathrm{C}$ stock in the $F F$ but to a much lesser extent (0.07 SD and -0.12 SD, respectively; $p<0.10$ ). Microelevation was positively related to $\mathrm{C}$ stock $(0.07 \mathrm{SD}$, Fig. 2), whereas $\mathrm{C}$ stock decreased with canopy openness (-0.12 SD, Fig. 2). Root turnover was the only significant factor affecting $\mathrm{C}$ stock in the $M S$ (Fig. 2), showing a pos itive relationship between both variables $(0.23 \mathrm{SD})$ but with a low fit $\left(R^{2}=0.09\right)$. When analyzing the data separately per stand type, the positive effect of the proportion of Norway spruce in litterfall and root turnover on $\mathrm{C}$ stock in the $F F$ and the $M S$ layers, respectively, was only significant $(p<0.05)$ in the mixed plot (Fig. 3). In addition, the struc tural equation models positively linked the proportion of Norway spruce to the $\mathrm{C}$ stored in the $M S$ in the mixed plot, yet this effect was not significant when data from all plots were analyzed together. Thus, $\mathrm{C}$ stock increases as the pro portion of the most recalcitrant species (Norway spruce) increases in the litterfall of the mixed plot (Fig. 4), and this 
Table 2 Mean characteristics and $\mathrm{C}$ stock ( \pm standard error) of the forest floor layers $(\mathrm{Ol}$ and $\mathrm{Of}+$ $\mathrm{Oh}$ ) and top $10 \mathrm{~cm}$ of mineral soil $(M S)$ in the experimental plots

\begin{tabular}{|c|c|c|c|}
\hline & European beech & Norway spruce & Mixture \\
\hline \multicolumn{4}{|l|}{ Litter layer $(\mathrm{Ol})$} \\
\hline Thickness $(\mathrm{cm})$ & $1.00 \pm 0.04 \mathrm{~b}$ & $1.25 \pm 0.06 \mathrm{a}$ & $1.23 \pm 0.06 \mathrm{a}$ \\
\hline Amount $\left(\mathrm{Mg} \mathrm{ha}^{-1}\right)$ & $11.28 \pm 0.49 \mathrm{c}$ & $16.47 \pm 0.80 \mathrm{a}$ & $12.97 \pm 0.71 b$ \\
\hline$[\mathrm{C}](\%)$ & $46.60 \pm 0.63 a$ & $48.38 \pm 0.66 \mathrm{a}$ & $43.55 \pm 0.71 b$ \\
\hline$[\mathrm{N}](\%)$ & $1.76 \pm 0.08 \mathrm{a}$ & $1.72 \pm 0.05 \mathrm{a}$ & $1.73 \pm 0.06 \mathrm{a}$ \\
\hline $\mathrm{C} / \mathrm{N}$ & $28.11 \pm 1.15 \mathrm{a}$ & $28.40 \pm 1.10 \mathrm{a}$ & $25.06 \pm 1.12 b$ \\
\hline Bulk density $\left(\mathrm{g} \mathrm{cm}^{-3}\right)$ & $0.130 \pm 0.008 \mathrm{ab}$ & $0.134 \pm 0.005 \mathrm{a}$ & $0.115 \pm 0.006 b$ \\
\hline $\mathrm{C}$ stock $\left(\mathrm{Mg} \mathrm{ha}^{-1}\right)$ & $5.45 \pm 0.24 \mathrm{~b}$ & $7.58 \pm 0.37 \mathrm{a}$ & $5.97 \pm 0.32 b$ \\
\hline \multicolumn{4}{|c|}{ Decomposed layer $(\mathrm{Of}+\mathrm{Oh})$} \\
\hline Thickness $(\mathrm{cm})$ & $0.96 \pm 0.05 \mathrm{c}$ & $3.50 \pm 0.11 \mathrm{a}$ & $2.29 \pm 0.09 b$ \\
\hline Amount $\left(\mathrm{Mg} \mathrm{ha}^{-1}\right)$ & $18.65 \pm 0.70 \mathrm{c}$ & $52.80 \pm 1.58 \mathrm{a}$ & $39.38 \pm 1.82 b$ \\
\hline$[\mathrm{C}](\%)$ & $32.98 \pm 2.30 \mathrm{~b}$ & $35.48 \pm 1.92 \mathrm{a}$ & $31.55 \pm 2.61 b$ \\
\hline$[\mathrm{N}](\%)$ & $1.66 \pm 0.11 \mathrm{a}$ & $1.42 \pm 0.06 \mathrm{~b}$ & $1.52 \pm 0.18 \mathrm{ab}$ \\
\hline $\mathrm{C}: \mathrm{N}$ & $22.29 \pm 1.51 \mathrm{ab}$ & $23.65 \pm 0.53 \mathrm{a}$ & $20.83 \pm 1.54 b$ \\
\hline Bulk density $\left(\mathrm{g} \mathrm{cm}^{-3}\right)$ & $0.287 \pm 0.018 b$ & $0.255 \pm 0.007 b$ & $0.385 \pm 0.016 \mathrm{a}$ \\
\hline Root density $\left(\mathrm{g} \mathrm{cm}^{-3}\right)$ & $0.078 \pm 0.001 b$ & $0.093 \pm 0.001 \mathrm{a}$ & $0.083 \pm 0.002 \mathrm{ab}$ \\
\hline $\mathrm{C}$ stock $\left(\mathrm{Mg} \mathrm{ha}^{-1}\right)$ & $6.79 \pm 0.35 c$ & $26.25 \pm 0.78 \mathrm{a}$ & $19.58 \pm 0.90 \mathrm{~b}$ \\
\hline \multicolumn{4}{|l|}{ Top mineral soil (MS) } \\
\hline$[\mathrm{C}](\%)$ & $2.79 \pm 0.06 \mathrm{~b}$ & $2.61 \pm 0.07 \mathrm{~b}$ & $3.73 \pm 0.12 \mathrm{a}$ \\
\hline$[\mathrm{N}](\%)$ & $0.13 \pm 0.01 \mathrm{~b}$ & $0.12 \pm 0.01 b$ & $0.21 \pm 0.01 \mathrm{a}$ \\
\hline $\mathrm{C}: \mathrm{N}$ & $21.94 \pm 0.39 \mathrm{a}$ & $21.73 \pm 0.30 \mathrm{a}$ & $18.14 \pm 0.29 b$ \\
\hline Bulk density $\left(\mathrm{g} \mathrm{cm}^{-3}\right)$ & $1.097 \pm 0.016 \mathrm{a}$ & $1.098 \pm 0.015 \mathrm{a}$ & $0.994 \pm 0.015 b$ \\
\hline Root density $\left(\mathrm{g} \mathrm{cm}^{-3}\right)$ & $0.072 \pm 0.001 \mathrm{a}$ & $0.072 \pm 0.001 \mathrm{a}$ & $0.061 \pm 0.001 b$ \\
\hline $\mathrm{C}$ stock $\left(\mathrm{Mg} \mathrm{ha}^{-1}\right)$ & $41.73 \pm 0.81 \mathrm{~b}$ & $41.93 \pm 0.98 b$ & $49.37 \pm 1.48 \mathrm{a}$ \\
\hline
\end{tabular}

Different letters between columns show significant differences $(p<0.05)$ between plots effect was not confounded with that of basal area $(p=0.85)$. We did not find any relationship between the studied covariates and the $\mathrm{C}$ stock whatever the soil layer ( $F F$ and $M S$ ) when Norway spruce was the dominant species in the stand (Fig. 3). Under European beech, only canopy openness $(-0.36 \mathrm{SD})$ and micro-elevation $(0.35 \mathrm{SD})$ were significantly related $(p<0.05)$ to $\mathrm{C}$ stock in the forest floor layer. The direction in which these factors affected $\mathrm{C}$ stock in the European beech plot was the same as when data from the three plots were analyzed together.

\subsection{Spatial distribution of SOC stock}

$\mathrm{C}$ stock in the forest floor showed a high spatial dependence $(\mathrm{C} /(\mathrm{C}+\mathrm{Co})>0.80)$ in the three stands (Table 3$)$ indicating that within plot variability may be mainly explained by the spatial structure of the stand. The semivariogram of $\mathrm{C}$ stock in the $\mathrm{FF}$ was similar for all the study plots, with almost the same spatial range (7.56-7.96 m) but with lower values of semivariance in the Norway spruce plot (Table 3). On the other hand, the C stock in the top mineral soil in the Norway spruce and

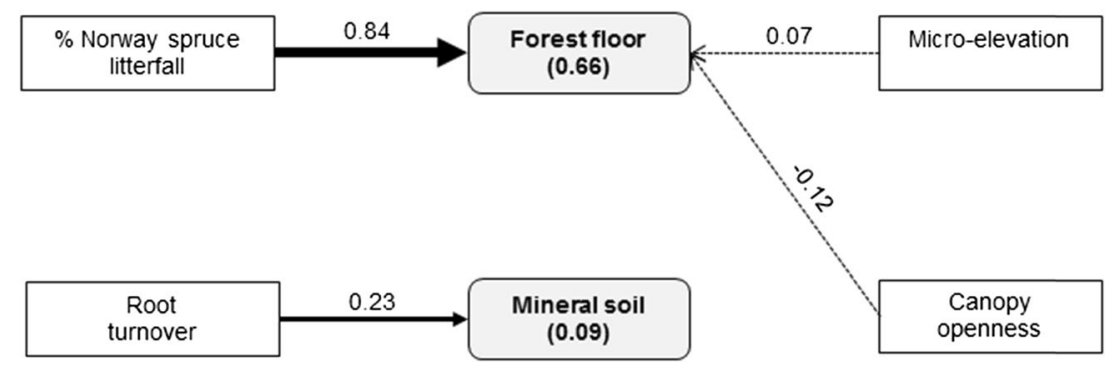

Fig. 2 Structural equation models depicting casual paths of uppermost forest soil layers $\mathrm{C}$ stocks (forest floor and mineral soil). Showed links were significant at $p<0.05$ (solid line) or marginally significant at $0.05<p<0.10$ (dashed line). Arrow width is proportional to standardized path coefficients (showed beside arrows). $R^{2}$ is showed beneath the variable names. Structural equation models were calculated using data from the three experimental plots 
European beech

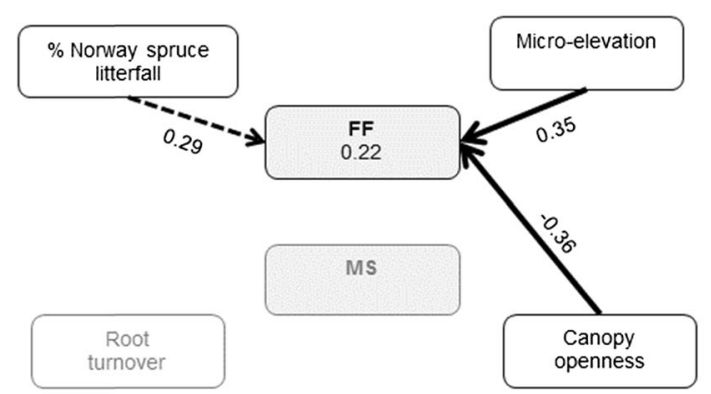

Norway spruce

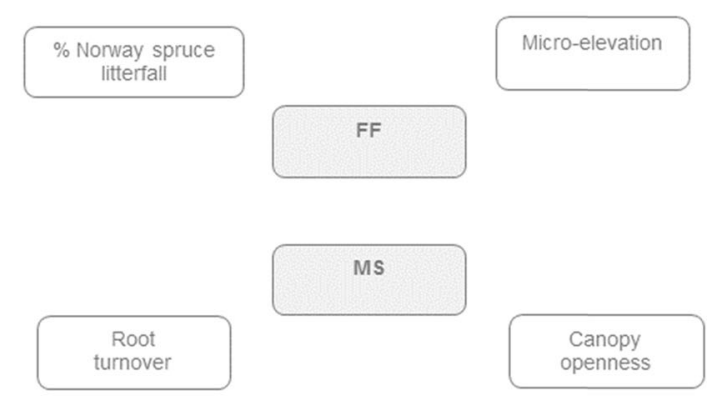

Mixed

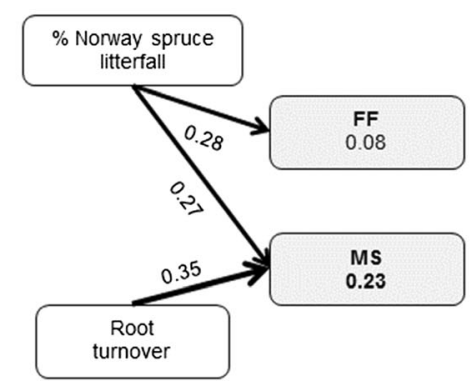

Micro-elevation
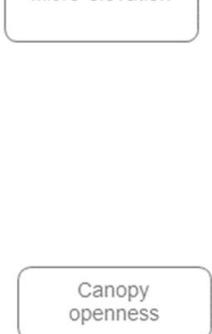

Fig. 3 Structural equation models depicting casual paths of uppermost forest soil layers $\mathrm{C}$ stocks (forest floor and mineral soil) per species composition type. Showed links were significant at $p<0.05$ (solid line)

European beech plots showed a null spatial dependence (i.e., $C /(C+C o)=0$, Table 3), indicative of random distribution, whereas in the mixed plot, the $\mathrm{C}$ stock in the $M S$ showed the highest spatial dependence $((C /(C+C o)=0.91)$ and a lower spatial range than $\mathrm{C}$ stock in the forest floor did (Table 3).

Point interpolation in the mixed plot by using universal kriging showed lower values of the diagnostic parameters than interpolation by ordinary kriging for both forest soil layers: forest floor $(M E=0.0021, R M S E=0.295, M S D R=1.035$ for

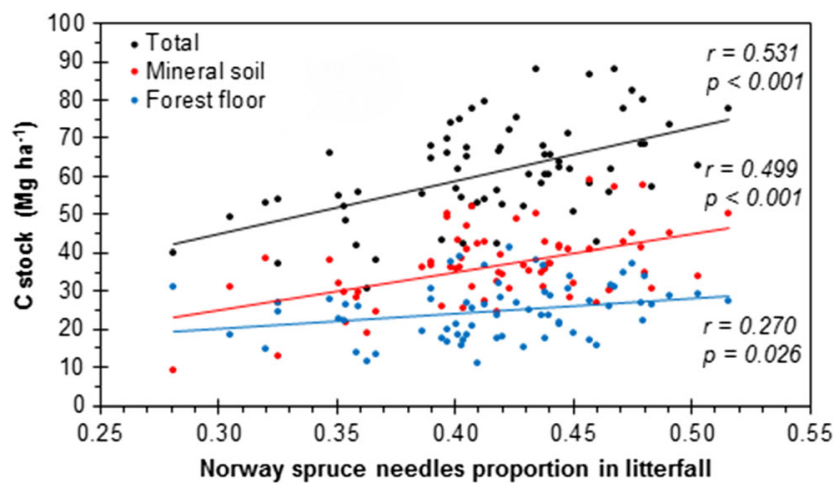

Fig. 4 Relationship of the $\mathrm{C}$ stock $\left(\mathrm{Mg} \mathrm{ha}^{-1}\right)$ in the forest floor $(\mathrm{Ol}+$ $O h+O f$, blue), uppermost $10 \mathrm{~cm}$ of mineral soil (red), and the total (forest floor + uppermost $10 \mathrm{~cm}$ of mineral soil, black) of the mixed plot and the estimated Norway spruce litterfall proportion $(n=77)$. The Pearson's correlation coefficient $(r)$ and the $p$ values are indicated for each relationship or marginally significant at $0.05<p<0.10$ (dashed line). Arrow width is proportional to standardized path coefficients (showed beside arrows). $R^{2}$ is showed beneath the variable names

universal kriging and $M E=0.0023, R M S E=0.297$, $M S D R=1.117$ for ordinary kriging) and mineral soil $\left(M E=6.4 \times 10^{-5}, R M S E=0.221, M S D R=1.044\right.$ for universal kriging and $M E=1.2 \times 10^{-3}, R M S E=0.223, M S D R=1.064$ for ordinary kriging). These results suggest a lower bias and greater precision when the significant ancillary variables, derived from SEM analyses, were included. This corroborates, at a finer spatial scale, the effect of litter species proportion and root turnover on SOC accumulation. Mapping interpolated values shows the spatial distribution of SOC stocks in the mixed plot (Fig. 5) and allows linking SOC stock to the spatial distribution and density of tree species.

\section{Discussion}

Our results confirmed the expectation of a different response of $\mathrm{C}$ attributes of forest soils to tree species composition (Table 2). The effect of tree species on soil $\mathrm{C}$ pools may be confounded by inherent site factors, such as parent material and soil texture (Baritz et al. 2010). However, the similarity in plot characteristics (soil type, parent material, and slope) and especially its proximity suggest that species composition is the main varying factor between selected areas. Additionally, differences in tree density and basal area between plots could have also masked individual effects attributable to species 
Table 3 Nugget $(\mathrm{Co})$, sill $(C)$, range $(\mathrm{m})$ parameters, and the coefficient of determination $\left(R^{2}\right)$ of the semivariogram spherical models fitted to the $\mathrm{C}$ stock of the forest floor $(F F)$ and mineral soil $(M S)$ layers in the different plots

\begin{tabular}{|c|c|c|c|c|c|c|c|}
\hline Plot & Layer & Nugget & Sill & Range & $\mathrm{C} /(\mathrm{C}+\mathrm{Co})$ & $R^{2}$ & $\mathrm{CV}$ \\
\hline \multirow[t]{2}{*}{ European beech } & $\mathrm{FF}$ & 0.028 & 0.108 & 7.96 & 0.79 & 0.76 & 0.33 \\
\hline & MS & \multicolumn{5}{|c|}{ Nugget model $[\mathrm{C} /(\mathrm{C}+\mathrm{Co})]=0$} & 0.17 \\
\hline \multirow[t]{2}{*}{ Norway spruce } & $\mathrm{FF}$ & 0.008 & 0.0469 & 7.56 & 0.85 & 0.94 & 0.23 \\
\hline & MS & \multicolumn{5}{|c|}{ Nugget model $[\mathrm{C} /(\mathrm{C}+\mathrm{Co})]=0$} & 0.20 \\
\hline \multirow[t]{2}{*}{ Mixture } & $\mathrm{FF}$ & 0.021 & 0.094 & 7.84 & 0.82 & 0.84 & 0.38 \\
\hline & MS & 0.005 & 0.050 & 6.16 & 0.91 & 0.98 & 0.26 \\
\hline
\end{tabular}

The proportion of the total variance explained by the spatial autocorrelation (i.e., $C / C+C o$ ) and the coefficient of variation $(\mathrm{CV})$ are indicated composition, but the lack of significant differences in litter inputs and canopy openness between plots suggests that species identity, rather than forest structure, was the major factor affecting ground conditions.

Our results suggest that litterfall was the main input to forest floor carbon as confirmed by the similarity in spatial ranges between plots (Table 3), the distance beyond which samples are spatially independent. We found a greater C accumulation in forest floor layers under Norway spruce than under European beech which is consistent with other observations in which conifers species stored greater amounts of SOC in the forest floor than deciduous species did (Augusto et al. 2015; Vesterdal et al. 2013). However, the lack of significant differences in litterfall inputs between plots seems to indicate that output processes are more important factors affecting forest floor $\mathrm{C}$ accumulation than the amount of litterfall per se. This is in agreement with previous studies in which differences in forest floor $\mathrm{C}$ accumulation under

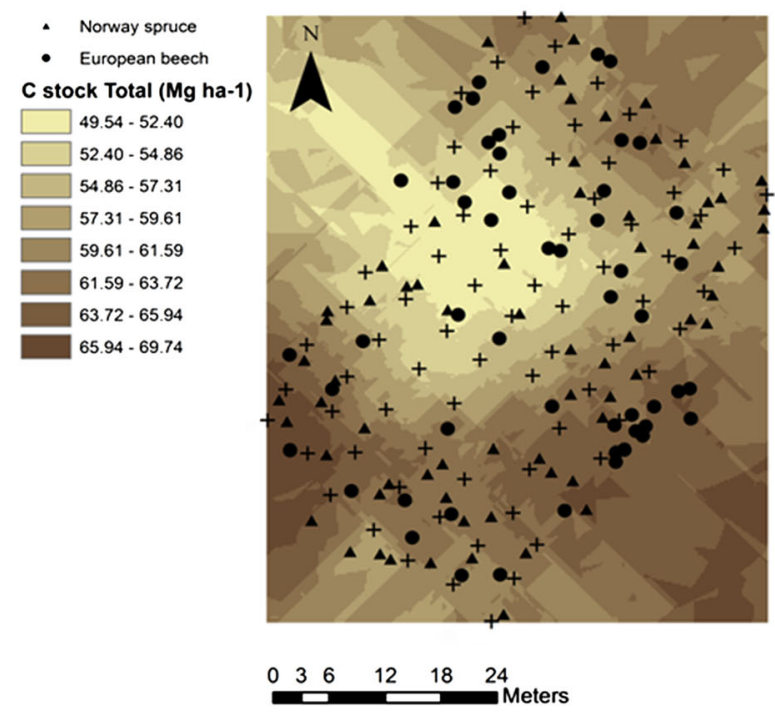

Fig. 5 Soil organic carbon stock $\left(\mathrm{Mg} \mathrm{ha}^{-1}\right)$ in forest soil in the mixed plot (left) and different admixture level intervals in the plot (right). Total C stock was calculated by summarizing the predictions of each forest soil layer (forest floor and uppermost $10 \mathrm{~cm}$ mineral soil). Predictions were made by universal kriging and using as ancillary variables the Norway spruce litter proportion for the forest floor and the Norway spruce litter proportion and root turnover for the mineral soil. Norway spruce and different tree species were mainly linked to output processes, such as decomposition, rather than to aboveground inputs (Augusto et al. 2002; Trum et al. 2011; Vesterdal et al. 2008). Additionally, we observed a positive association between root turnover and $\mathrm{C}$ accumulation in the top mineral soil layer. However, the low explanatory power of the fitted model suggests that other factors, such as output processes from the forest floor, can be important to explain $\mathrm{C}$ distribution in forest soils. On a given site, litter quality and its interaction with site properties are generally considered as the main factors controlling early phases of decomposition in forest ecosystems (Augusto et al. 2015; Blair et al. 1990). Our results provide consistent evidence of the importance of the conifer litterfall mass on the buildup of forest floor humus in forest soils (Figs. 2, 3, and 4), besides microtopography and canopy openness. Conifer litter contains more recalcitrant constituents than broadleaf litter does (Berg 2000), which may result in a greater litter accumulation under Norway spruce when

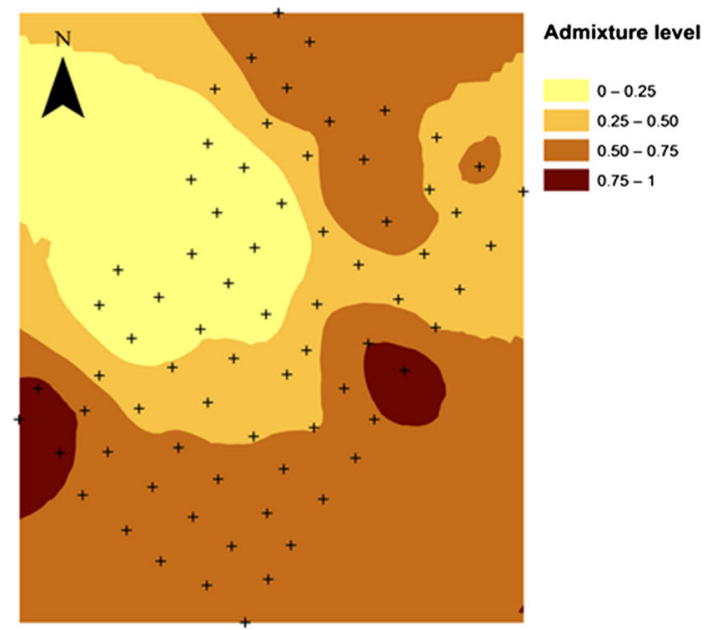

European beech individual positions are marked with triangles and circles, respectively. Admixture level (0-1) was calculated from the proportion of each tree species in an area of $5 \mathrm{~m}$ around each sampling point. Admixture level equal to 1 corresponds to areas in which the basal area of each tree species were the same, whereas admixture level equal to 0 corresponds to those areas where only one tree species was found 
compared to broadleaved stands because of its lower decomposition rate (Berg and McClaugherty 2008). Jonard et al. (2006) also found a positive relationship between the forest floor mass and the litterfall proportion of the most recalcitrant litter (beech litter in this case) in mixed stands of oak and European beech. Other studies have linked the slower litter decay under conifer species to adverse microenvironmental conditions, resulting from the associated litter accumulation, that constrain decomposition (Albers et al. 2004; Berger and Berger 2012). Tree species composition also affects decomposition through modifications of ground climate, understory vegetation or soil properties, and biota as a consequence of differences in tree canopy characteristics (Albers et al. 2004; Jonard et al. 2008; Prescott et al. 2000). In this regard, differences in soil fauna composition, especially the lower abundance and diversity of earthworms in conifer stands as compared to broadleaved stands (De Schrijver et al. 2012; Elmer et al. 2004), might also contribute to differences in soil C distribution between these species. Indeed, bioturbation has been identified as a key factor controlling the incorporation of SOC into the mineral soil (Vande Walle et al. 2001) through the transformation of litter into fecal matter and the transport into deeper mineral soil horizons by endogeic earthworm species (Marhan and Scheu 2006). Moreover, the general higher packing of Norway spruce stands can intercept higher amount of solar radiation and rainfall (Christiansen et al. 2010), which can further slowdown decomposition through diminishing the activity of soil biota.

Contrastingly to the forest floor, spatial analyses showed a random distribution of $\mathrm{C}$ stock in the mineral soil in the Norway spruce and European beech plots (Table 3) due to the greater vegetation uniformity of monodominant stands. However, $\mathrm{C}$ stock in the mineral soil in the mixed plot showed the highest spatial dependence ( $>90 \%$ ) of all studied variables. In addition, its lower range indicates a spatial autocorrelation at a finer scale than $\mathrm{C}$ stock in the forest floor layer suggesting that underlying mechanisms controlling $\mathrm{C}$ accumulation may be different for both layers. Indeed, we found no differences in $\mathrm{C}$ stock in the uppermost mineral soil between Norway spruce and European beech but, interestingly, the mixed plot showed greater values of $\mathrm{C}$ stock (by $18 \%$ ) in the mineral soil than Norway spruce and European beech. The SEM analysis linked $\mathrm{C}$ stock in the mineral soil to root turnover (Fig. 2), but when plots were separately analyzed, this effect was only noticed in the mixed plot (Fig. 3). Thus, mechanisms controlling $\mathrm{C}$ accumulation may be different not only between forest soil layers but also between plots, suggesting that they might vary with local species composition. Furthermore, the Norway spruce litter proportion was also linked to the $\mathrm{C}$ stock in the mineral soil at the mixed plot (Figs. 3 and 4). This might indicate a non-additive effect of litter quality on SOC in the mineral soil when both species are mixed. Tree species exhibit a greater crown plasticity when they grow in mixed stands
(Pretzsch 2014), which could induce a greater heterogeneity of microenvironmental conditions in forest soil at a finer spatial scale (He et al. 2014). This microenvironmental heterogeneity, together with the different characteristics and proportion of litter of both species, might affect root turnover and decomposition processes (Berger and Berger 2012; Gill and Jackson 2000) explaining both the high spatial variability of SOC stock and the higher incorporation of SOC into the top mineral soil. The spatial analyses confirm that the inclusion of the ancillary variables significantly improved prediction models in the mixed plot, validating at a finer spatial scale the results from structural equation models.

New trends in forestry that seek the conversion of monocultures into mixed-species forest are based on the maximization of complementary effects between tree species to promote greater level of ecosystem functions and services. A promising tool to manage complementarity in mixtures may be the modification of the stand structure, a well-known silvicultural tool widely used for managing forests (Bravo-Oviedo et al. 2014). We found that the greater values of SOC stock corresponded to areas of high-medium tree density and admixture proportion (Fig. 5), validating the results from interplot comparison, and demonstrating that areas with high potentiality for $\mathrm{C}$ sequestration in the mineral soil within a stand can be identified by analyzing the spatial arrangement of tree species in the mixed stand. This may help to improve the predictions of the effect of the spatial distribution of tree species within mixed stands and to optimize the spatial organization of the mixture (Wälder et al. 2008). The high spatial dependence of $\mathrm{C}$ stocks also provides evidence of the need for the consideration of spatial distribution of tree species on modeling approaches aimed at estimating $\mathrm{C}$ sequestration in forest soils, especially in mixed forests.

\section{Conclusions}

Our results suggest that local species composition plays an important role on SOC stock and its spatial distribution in forest ecosystems. In our study sites, $\mathrm{C}$ accumulation in the forest floor layer was mainly related to the proportion of the most recalcitrant species (Norway spruce) in the litterfall, whereas $\mathrm{C}$ stock in the mineral soil was mainly linked to root turnover. This effect was remarkable when both species were growing together suggesting a complementarity between tree species regarding $\mathrm{C}$ sequestration. Norway spruce litter favored SOC accumulation in the forest floor and the mineral soil, whereas $\mathrm{C}$ incorporation into the uppermost mineral soil was also promoted by root turnover, which was greater under European beech. Spatial analyses corroborated that species composition constituted the main source of spatial variability of SOC stock in the mixed 
stand. These results can have practical implication for silviculture practices and for the design of adaptive strategies in a context of climate change. The conversion of these monodominant plantations into mixed stands where different species are mixed individually might enhance soil organic matter accumulation and stabilization in the mineral layers, and therefore the long-term storage of $\mathrm{C}$.

Acknowledgments Authors want to thank Marko Stojanović for his invaluable help with soil sampling. We are also grateful to Antonín Martiník for his continuous support and to Lumír Dobrovolný for his assistance with the field map technology. Thank you also to three anonymous reviewers and to the editor who provided useful suggestions that helped to improve this manuscript.

\section{Compliance with ethical standards}

Funding VR and EA were supported by a postdoctoral grant from the OP Education for Competitiveness (European Social Fund and Czech Republic Ministry of Education and Youth CZ.1.07/2.3.00/ 30.0017). EA was also supported by a FSR Incoming Post-doctoral Fellowship of the Académie Universitaire "Louvain" and the European Commission and VR by the government of South Africa (NRF Freestanding Post-doctoral Fellowship).

\section{References}

Albers D, Migge S, Schaefer M, Scheu S (2004) Decomposition of beech leaves (Fagus sylvatica) and spruce needles (Picea abies) in pure and mixed stands of beech and spruce. Soil Biol Biochem 36:155164

Augusto L, Ranger J, Binkley D, Rothe A (2002) Impact of several common tree species of European temperate forests on soil fertility. Ann For Sci 59:233-253

Augusto L, De Schrijver A, Vesterdal L, Smolander A, Prescott C, Ranger J (2015) Influences of evergreen gymnosperm and deciduous angiosperm tree species on the functioning of temperate and boreal forests. Biol Rev 90:444 466

Baritz R, Seufert G, Montanarella L, Van Ranst E (2010) Carbon concentrations and stocks in forest soils of Europe. For Ecol Manage 260: 262-277

Berg B (2000) Litter decomposition and organic matter turnover in northern forest soils. For Ecol Manage 133:13-22

Berg B, McClaugherty C (2008) Plant litter. Decomposition, humus formation, carbon sequestration. Springer, Berlin

Berger TW, Berger P (2012) Greater accumulation of litter in spruce (Picea abies) compared to beech (Fagus sylvatica) stands is not a consequence of the inherent recalcitrance of needles. Plant Soil 358: 349-369

Blair JM, Parmelee RW, Beare MH (1990) Decay rates, nitrogen fluxes, and decomposer communities of single- and mixed-species foliar litter. Ecology 71:1976-1985

Bravo-Oviedo A, Pretzsch H, Ammer C, Andenmatten E, Barbati A, Barreiro S, Brang P, Bravo F, Coll L, Corona P, den Ouden J, Ducey MJ, Forrester DI, Giergiczny M, Jacobsen JB, Lesinski J, Löf M, Mason WL, Matovic B, Metslaid M, Morneau F, Motiejunaite J, O'Reilly C, Pach M, Ponette Q, Rio M, Short I, Skovsgaard JP, Soliño M, Spathelf P, Sterba H, Stojanovic D, Strelcova K, Svoboda M, Verheyen K, Lüpke N, Zlatanov T
(2014) European mixed forests: definition and research perspectives. Forest Systems 23:518-533

Chapin F III (2003) Effects of plant traits on ecosystem and regional processes: a conceptual framework for predicting the consequences of global change. Ann Bot 91:455-463

Christiansen JR, Vesterdal L, Callesen I, Elberling B, Schmidt IK, Gundersen P (2010) Role of six European tree species and landuse legacy for nitrogen and water budgets in forests. Global Change Biol 16:2224-2240

De Schrijver A, de Frenne P, Staelens J, Verstraeten G, Muys B, Vesterdal L, Wuyts K, Van Nevel L, Schelfhout S, De Neve S, Verheyen K (2012) Tree species traits cause divergence in soil acidification during four decades of postagricultural forest development. Global Change Biol 18:1127-1140

Elmer M, La France M, Förster G, Roth M (2004) Changes in the decomposer community when converting spruce monocultures to mixed spruce/beech stands. Plant Soil 264:97-109

Ferrari JB, Sugita S (1996) A spatially explicit model of leaf litter fall in hemlock hardwood forests. Can J Forest Res 26:1905-1913

Finér L, Helmisaari H-S, Lohmus K, Majdi H, Brunner I, Børja I, Eldhuset T, Godbold D, Grebenc T, Konopka B, Kraigher H, Möttönen M-R, Ohashi M, Oleksyn J, Ostonen I, Uri V, Vanguelova E (2007) Variation in fine root biomass of three European tree species: beech (Fagus sylvatica L.), Norway spruce (Picea abies L. Karst.), and Scots pine (Pinus sylvestris L.). Plant Biosyst 141:394-405

Galka B, Labaz B, Bogacz A, Bojko O, Kabala C (2014) Conversion of Norway spruce forests will reduce organic carbon pools in the mountain soils of SW Poland. Geoderma 213:287-295

Gill RA, Jackson RB (2000) Global patterns of root turnover for terrestrial ecosystems. New Phytol 147:13-31

Grace JB (2006) Structural equation modeling and natural systems. Cambridge University Press

Hagen-Thorn A, Callesen I, Armolaitis K, Nihlgard B (2004) The impact of six European tree species on the chemistry of mineral topsoil in forest plantations on former agricultural land. For Ecol Manage 195: 373-384

Hansson K, Helmisaari HS, Sah SP, Lange H (2013) Fine root production and turnover of tree and understorey vegetation in Scots pine, silver birch and Norway spruce stands in SW Sweden. For Ecol Manage 309:58-65

He L, Ivanov VI, Bohrer G, Maurer KD, Vogel CS, Moghaddam M (2014) Effects of fine-scale soil moisture and canopy heterogeneity on energy and water fluxes in a northern temperate mixed forest. Agri Forest Meteorol 184:243-256

Hengl T (2007) A practical guide to geostatistical mapping of environmental variables. Office for Official Publications of the European Communities, Luxembourg

IUSS Working Group WRB (2006) World reference base for soil resources, second edition. World Soil Resources Reports $N^{\circ} 103$. FAO, Rome, Italy

Jandl R, Lindner M, Vesterdal L, Bauwens B, Baritz R, Hagedorn F, Johnson DW, Minkkinen K, Byrne KA (2007) How strongly can forest management influence soil carbon sequestration? Geoderma 137:253-268

Jandl R, Rodeghiero M, Martinez C, Cotrufo MF, Bampa F, van Wesemael B, Harrison RB, Guerrini IA, de Richter DD, Rustad L, Lorenz K, Chabbi A, Miglietta F (2014) Current status, uncertainty and future needs in soil organic carbon monitoring. Sci Total Environ 468-469:376-383

Jonard M, Andre F, Ponette Q (2006) Modelling leaf dispersal in mixed hardwood forests using a ballistic approach. Ecology 87:2306-2318

Jonard M, Andre F, Ponette Q (2008) Tree species mediated effects on leaf litter dynamics in pure and mixed stands of oak and beech. Can J For Res 38:528-538 
Jonard M, Caignet I, Ponette Q, Nicolas M (2013) Évolution du carbone des sols forestiers de France métropolitaine - Détection et quantification à partir des données mesurées sur le réseau RENECOFOR. Rapport final d'étude subventionnée par le ministère de l'Agriculture, de l'Agroalimentaire et de la Forêt. France

Marhan S, Scheu S (2006) Mixing of different mineral soil layers by endogeic earthworms affects carbon and nitrogen mineralization. Biol Fert Soils 42:308-314

O'Hara KL (2014) Multiaged silviculture: managing for complex forest stand structures. Oxford University Press, Oxford, UK, 213 p

Pan YD, Birdsey RA, Fang JY, Houghton R, Kauppi PE, Kurz WA, Phillips OL, Shvidenko A, Lewis SL, Canadell JG, Ciais P, Jackson RB, Pacala SW, McGuire AD, Piao SL, Rautiainen A, Sitch S, Hayes D (2011) A large and persistent carbon sink in the world's forests. Science 333:988-993

Prescott CE, Zabek LM, Staley CL, Kabzems R (2000) Decomposition of broadleaf and needle litter in forests of British Columbia: influences of litter type, forest type, and litter mixtures. Can J For Res 30:17421750

Pretzsch H (2014) Canopy space filling and tree crown morphology in mixed-species stands compared with monocultures. For Ecol Manage 327:251-264

Rosseel Y (2012) Lavaan: an R package for structural equation modeling. J Stat Softw 48:1-36

Rossiter DG (2007) Technical note: co-kriging with the gstat package of the $\mathrm{R}$ environment for statistical computing, 2nd edn. International Institute for Geo-information Science \& Earth Observation, Enschede, Netherlands

Stockmann U, Adams M, Crawford JW, Field DJ, Henakaarchchi N, Jenkins M, Minasny B, McBratney AB, deCourcelles VR, Singh K, Wheeler I, Abbott L, Angers D, Baldock J, Bird M, Brookes
PC, Chenu C, Jastrow J, Lal R, Lehmann CJ, O’Donnell AG, Parton WJ, Whitehead D, Zimmermann M (2013) The knowns, known unknowns and unknowns of sequestration of soil organic carbon. Agric Ecosyst Environ 164:80-99

Trum F, Titeux H, Ranger J, Delvaux B (2011) Influence of tree species on carbon and nitrogen transformation patterns in forest floor profiles. Ann For Sci 68:837-847

UHUL (2007) National Forest Inventory in the Czech Republic 20012004. Forest Management Institut, Brandýs nad Labem, Czech Republic

van Delft B, de Waal RW, Kemmers RH, Mekkink P, Sevink J (2006) Field guide humus forms. Description and classification of humus forms for ecological applications, Alterra, Wageningen, In

Vande Walle I, Mussche S, Samson R, Lust N, Lemeur R (2001) The above- and belowground carbon pools of two mixed deciduous forest stands located in East-Flanders (Belgium). Ann For Sci 58:507517

Vesterdal L, Schmidt IK, Callesen I, Nilsson LO, Gundersen P (2008) Carbon and nitrogen in forest floor and mineral soil under six common European tree species. For Ecol Manage 255:35-48

Vesterdal L, Clarke N, Sigurdsson BD, Gundersen P (2013) Do tree species influence soil carbon stocks in temperate and boreal forests? For Ecol Manage 309:4-18

Wälder K, Frischbier N, Bredemeier M, Näther W, Wagner S (2008) Analysis of OF-layer humus mass variation in a mixed stand of European beech and Norway spruce: an application of structural equation modelling. Ecol Model 213: 319-330

Wardle DA, Bardgett RD, Klironomos JN, Setälä H, van der Putten W, Wall DH (2004) Ecological linkages between aboveground and belowground biota. Science 304:1629-1633 